\title{
Analisis Metode Standardized Unitless Rating (SUR) Dalam Pemilihan Prioritas Vendor Trucking
}

\author{
Darfial Guslan ${ }^{1}$, Yahya Amri Nasrullah² \\ Program Studi D4 Logistik Bisnis Politeknik Pos Indonesia ${ }^{1}$ \\ Email : darfialguslan@poltekpos.ac.id \\ Program Studi D4 Logistik Bisnis Politeknik Pos Indonesia ${ }^{2}$ \\ Email : yahya.amri91@yahoo.com
}

\begin{abstract}
Abstrak
Guna peningkatan pelayanan yang diberikan demi terciptanya kepuasan pelanggan secara maksimal, PT Yusen Logistics Indonesia harus mampu menentukan dan memilih mitra kerja terbaik yang memiliki kualitas kinerja sesuai dengan standar yang telah ditetapkan perusahaan, khususnya dalam memilih vendor. Adapun metode yang digunakan dalam penelitian ini adalah metode Standardized Unitless Rating (SUR). Metode SUR merupakan suatu metode yang digunakan untuk menilai kinerja vendor serta memperhitungkan tingkat kepuasan dan tingkat keragu-raguan dalam mengukur kinerja vendor tersebut. Dari hasil perhitungan dengan metode SUR diperoleh urutan sebagai berikut PT Pancaran Darat Trans $(0,407)$, PT Gelang Trans $(0,134)$, PT Orient Future Trans $(0,078)$, PT Pro-XT $(0,063)$, dan PT KMN Trans $(-0,537)$.
\end{abstract}

Kata Kunci : Vendor, Trucking, Standardized Unitless Rating (SUR), pemrograman linier

\begin{abstract}
Improving the services provided for maximum customer satisfaction, PT Yusen Logistics Indonesia must be able to determine and choose the best work partners who have quality performance in accordance with the standards set by the company, especially in selecting vendors. The method used in this study is the Standardized Unitless Rating (SUR) method. The Standardized Unitless Rating (SUR) method is a method used to assess vendor performance and take into account the level of satisfaction and the level of doubt in measuring the vendor's performance. From the results of calculations with the SUR method obtained the following sequence PT Pancaran Land Trans (0.407), PT Gelang Trans (0.134), PT Orient Future Trans (0.078), PT Pro-XT (0.063), and PT KMN Trans (0.537).
\end{abstract}

Keywords: Vendors, Trucking, Standardized Unitless Rating (SUR), Linear Programming

\section{PENDAhuluaN}

Berdasarkan masalah mengenai over inquiry order yang terjadi di PT Yusen Logistics Indonesia pada 2 bulan terakhir yaitu bulan Maret dan April sehingga banyak permintaan konsumen yang tidak dapat terpenuhi dengan baik dan memilih jasa perusahaan trucking lain, sehingga berpotensi akan mengurangi kepercayaan konsumen terhadap perusahaan dan berpotensi menimbulkan kerugian, selain itu keterbatasan dari ketersediaan trailer truck pada PT Yusen Logistics Indonesia mengharuskan perusahaan melakukan kerjasama dengan mitra kerja atau vendor untuk penyediaan trailer trucking. Untuk itu pemilihan vendor harus dilakukan oleh perusahaan dalam upaya menanggulangi permasalahan yang dihadapai oleh perusahaan dalam pemenuhan permintaan dari konsumen, adapun beberapa rumusan masalah yang diangkat dalam penelitian ini antara lain :

1. Kriteria- kriteria apa saja yang digunakan untuk menentukan urutan prioritas penilaian dan pemilihan vendor trucking di PT Yusen Logistics Indonesia?

2. Bagaimanakah urutan prioritas dalam penilaian vendor trucking di PT Yusen Logistics Indonesia berdasarkan metode Standardized Unitless Rating (SUR)?

3. Bagaimanakah urutan prioritas dalam penilaian vendor trucking di PT Yusen Logistics Indonesia berdasarkan metode Linear Programming? 
Tujuan dari penelitian ini yaitu :

1. Untuk mengetahui kriteria- kriteria apa saja yang digunakan untuk menentukan urutan prioritas penilaian dan pemilihan vendor trucking untuk PT Yusen Logistics Indonesia.

2. Untuk mengetahui urutan prioritas dalam penilaian vendor trucking di PT Yusen Logistics Indonesia dengan menggunakan metode Standardized Unitless Rating (SUR).

3. Untuk mengetahui urutan prioritas dalam penilaian vendor trucking di PT Yusen Logistics Indonesia dengan menggunakan metode Linear Programming.

\section{MODEL PENGOLAHAN DATA}

Metode Standarized Unitless Rating dikembangkan oleh Li et al. (1997) pada penelitiannya yang berjudul A new Measurement for Supplier Performance Evaluation. Metode digunakan untuk menentukan urutan prioritas supplier dan memeberikan rekomendasi kepada pihak perusahaan untuk memilih supplier-supplier tertentu dalam memasok bahan baku dalam hal ini adalah pengadaan trucking. Adapun model perhitungan yang dipakai penulis untuk memecahkan masalah yang terjadi dengan beberapa tahapan sebagai berikut:

1. Penentuan skala pengukuran kepuasan untuk penilaian kinerja tiap-tiap vendor dalam melaksanakan aktivitas penyediaan spare parts berdasarkan kriteria performansi yang telah ditentukan.

2. Mengukur kepuasan evaluator $1(x)$ dan evaluator $(y)$ dengan cara membagikan lembaran kuesioner mengenai penilaian kinerja tiap-tiap vendor dalam melaksanakan aktivitas penyediaan spare parts. Penilaian ini ditentukan dengan pemberian bobot pada tiap-tiap criteria.

3. Menentukan nilai rata-rata kepuasan kriteria performansi ke-j untuk vendor ke-i dengan menggunakan rumus sebagai berikut:

$$
a_{i j}=\frac{x_{i j}+y_{i j}}{2}
$$

4. Untuk menunjukkan angka keragu-raguan dari nilai kepuasan untuk kriteria performansi ke-j untuk vendor ke-i adalah dengan menggunakan rumus sebagai berikut:

$$
r_{i j}=\left|x_{i j}-y_{i j}\right|
$$

5. Kemudian menghitung nilai rata-rata untuk kriteria performansi $j$ untuk $m$ vendor secara keseluruhan $\left(a_{j}\right)$.

6. Mencari nilai maksimum dan minimum untuk masing-masing kriteria amax $j$ untuk nilai maksimum rata-rata penilaian untuk kriteria performansi $j$ untuk $m$ vendor, sedangkan amin $j$ untuk nilai minimum rata-rata penilaian untuk kriteria performansi $j$ untuk $m$ vendor.

7. Menghitung nilai Standardized Unitless Rating (SUR) dengan menggunakan rumus sebagai berikut:

$$
S U R_{i}=\sum_{j=1}^{n}\left[\frac{a_{i j}-\bar{a}_{i j}}{a_{\max j}-a_{\min j}}\right] \times\left[1-r_{i j}\right] \times\left[\frac{W_{j}}{\sum_{j=1}^{n}\left|W_{j}\right|}\right]
$$

\section{HASIL PENELITIAN DAN PEMBAHASAN}

\subsection{Pengumpulan Data}

\subsubsection{Pengisian Kuesioner}

Setelah data-data sekunder yang berhubungan dengan pembuatan laporan ini diperoleh, maka langkah selanjutnya Penulis membuat kuesioner dan menyebarkan kuesioner tersebut kepada Asst. Manager Logistics Dept (evaluator 1) dan Staff Operational Trucking (evaluator 2). 


\subsection{Pengolahan Data}

\subsubsection{Data Jumlah}

Langkah awal dalam menggunakan metode Standardized Unitless Rating (SUR) ialah dengan menentukan vendor yang akan digunakan. Penulis membuat tabel yang berisikan nama vendor, disusun berdasarkan urutan vendor 1 hingga vendor 5 .

Tabel 1 Data Vendor

\begin{tabular}{|c|l|l|}
\hline No. & \multicolumn{1}{|c|}{ Nama Vendor } & \multicolumn{1}{|c|}{ Keterangan } \\
\hline 1 & PT Pancaran Darat Transport & Vendor 1 \\
\hline 2 & PT Orient Future Lestari & Vendor 2 \\
\hline 3 & PT Pro XT & Vendor 3 \\
\hline 4 & PT KMN Trans & Vendor 4 \\
\hline 5 & PT Gelang Trans & Vendor 5 \\
\hline
\end{tabular}

\subsubsection{Menentukan Kriteria Performansi}

Setelah mengetahui jumlah vendor yang akan dianalisis, maka langkah selanjutnya adalah menetapkan kriteria performansi. Dalam penentuan kriteria performansi ini, penulis mengajukan beberapa kriteria kepada pihak perusahaan. Adapun kriteria dan sub kriteria performansi yang diajukan penulis kepada pihak perusahaan adalah sebagai berikut:

1. Kualitas Pelayanan vendor (Quality)

a. Kualitas dan kondisi kendaraan

b. Kesesuaian jenis armada yang dimiliki

c. Ketersediaan stock armada

d. Safety dalam bekerja

2. Harga (Price)

a. Harga yang ditawarkan

b. Adanya potongan harga

c. Kondisi finansial vendor

3. Pengiriman (Delivery)

a. Kecepatan dalam pengiriman armada

b. Kecepatan pengiriman barang ke customer

c. Ketepatan dalam pengiriman

4. Flexible (Flexibility).

a. Kemudahan dalam antisipasi perubahan permintaan

b. Kemudahan dalam pemesanan armada trucking

5. Kemampuan vendor dalam memberikan pelayanan yang cepat dan daya tanggap (responsiveness)

a. Kesigapan vendor dalam memberikan pelayanan

b. Tanggap dalam menyampaikan segala informasi

c. Tanggap dalam keluhan

d. Tanggung jawab 


\subsubsection{Pembobotan}

Cara penetapan persentase pada setiap kriteria yang akan dianalisis dapat dilihat pada tabel berikut di bawah ini:

Tabel 2 Persentase Setiap Kriteria

\begin{tabular}{|c|l|c|}
\hline No. & \multicolumn{1}{|c|}{ Kriteria } & Penilaian \\
\hline 1. & Kualitas pelayanan vendor (Quality) & $25 \%$ \\
\hline 2. & Harga (Price) & $25 \%$ \\
\hline 3. & Pengiriman (Delivery) & $15 \%$ \\
\hline 4. & $\begin{array}{l}\text { Kemampuan vendor dalam } \\
\text { memberikan pelayanan yang cepat dan } \\
\text { tanggap (Responsiveness) }\end{array}$ & $10 \%$ \\
\hline 5. & $\begin{array}{l}\text { Kemudahan yang diberikan oleh vendor } \\
\text { (Flexibility) }\end{array}$ & $\mathbf{1 0 0 \%}$ \\
\hline \multicolumn{2}{|c|}{ Jumlah } & \\
\hline
\end{tabular}

\subsubsection{Pengukuran Kepuasan Evaluator $1(x)$ dan Evaluator $2(y)$}

Berdasarkan penilaian yang diberikan oleh evaluator 1 (HD procurement) sebagai kepala departemen dalam penentu keputusan $(x)$ dan evaluator 2 (staff Procurement)dapat melakukan pinilaian sesuai dengan keadaan yang terjadi di lapangan $(y)$, maka diperoleh nilai kualitatif atas penilaian terhadap kriteria performansi yang telah ditentukan sebelumnya pada kuesioner.

\section{Tabel 3 Hasil Pengukuran Kepuasan Evaluator 1 (x) dan Evaluator 2 (y) Terhadap Kinerja Para Vendor

\begin{tabular}{|c|c|c|c|c|c|c|c|c|c|c|}
\hline \multirow{2}{*}{$\begin{array}{c}\text { Kriteria } \\
\text { Performansi }(j)\end{array}$} & \multicolumn{8}{|c|}{ Pengukuran Kriteria Performansi } \\
\cline { 2 - 12 } & \multicolumn{2}{|c|}{ Vendor 1} & \multicolumn{2}{|c|}{ Vendor 2 } & \multicolumn{2}{|c|}{ Vendor 3 } & \multicolumn{3}{|c|}{ Vendor 4} & \multicolumn{3}{|c|}{ Vendor 5} \\
\cline { 2 - 12 } & $\mathrm{x}$ & $\mathrm{y}$ & $\mathrm{x}$ & $\mathrm{y}$ & $\mathrm{x}$ & $\mathrm{y}$ & $\mathrm{x}$ & $\mathrm{y}$ & $\mathrm{x}$ & $\mathrm{y}$ \\
\hline Quality & 17 & 16 & 16 & 16 & 14 & 15 & 14 & 14 & 14 & 15 \\
\hline Price & 12 & 11 & 11 & 11 & 11 & 12 & 11 & 10 & 11 & 11 \\
\hline Delivery & 13 & 13 & 13 & 12 & 11 & 12 & 10 & 12 & 12 & 14 \\
\hline Responsiveness & 16 & 19 & 16 & 18 & 16 & 18 & 16 & 18 & 16 & 20 \\
\hline Flexibility & 10 & 9 & 9 & 9 & 8 & 8 & 6 & 8 & 8 & 10 \\
\hline
\end{tabular}

\subsection{Hasil Pengolahan Data}

\subsubsection{Metode Standardized Unitless Rating (SUR)}

Setelah tahap pengumpulan data, maka dilakukan pengolahan data. Ada beberapa tahapan yang akan dilakukan sehubungan dengan pemilihan vendor prioritas dengan menggunakan metode Standardized Unitless Rating (SUR) bisa dilihat pada tabel 4. 
Tabel 4 Hasil Perhitungan Metode SUR

\begin{tabular}{|c|c|c|c|c|c|}
\hline \multirow{2}{*}{ Vendor (i) } & \multicolumn{5}{|c|}{ Kriteria Performansi (j) } \\
\hline & Quality & Price & Delivery & Responsiveness & Flexibelity \\
\hline \multirow{2}{*}{$\begin{array}{c}1 \\
\text { NILAI SUR }\end{array}$} & 0,139 & 0,099 & 0,1 & 0,029 & 0,04 \\
\hline & \multicolumn{5}{|c|}{0,407} \\
\hline \multirow{2}{*}{$\begin{array}{c}2 \\
\text { NILAI SUR }\end{array}$} & 0,09 & $-0,025$ & 0,037 & $-0,044$ & 0,02 \\
\hline & \multicolumn{5}{|c|}{0,078} \\
\hline \multirow{2}{*}{$\begin{array}{c}3 \\
\text { NILAI SUR }\end{array}$} & $-0,059$ & 0,099 & 0,087 & $-0,044$ & $-0,02$ \\
\hline & \multicolumn{5}{|c|}{0,063} \\
\hline \multirow{2}{*}{$\begin{array}{c}4 \\
\text { NILAI SUR }\end{array}$} & $-0,138$ & $-0,149$ & $-0,147$ & $-0,044$ & $-0,059$ \\
\hline & \multicolumn{5}{|c|}{$-0,537$} \\
\hline \multirow{2}{*}{$\begin{array}{c}5 \\
\text { NILAI SUR }\end{array}$} & $-0,06$ & $-0,025$ & 0,098 & 0,101 & 0,02 \\
\hline & \multicolumn{5}{|c|}{0,134} \\
\hline$a \max$ & 0,165 & 0,115 & 0,130 & 0,180 & 0,095 \\
\hline$a_{\min }$ & 0,140 & 0,105 & 0,110 & 0,170 & 0,070 \\
\hline $\bar{a}$ & 0,151 & 0,111 & 0,122 & 0,173 & 0,085 \\
\hline
\end{tabular}

Tabel 5 Urutan Vendor Berdasarkan Metode SUR

\begin{tabular}{|c|l|c|}
\hline No. & \multicolumn{1}{|c|}{ Nama Vendor } & Nilai SUR \\
\hline 1 & PT Pancaran Darat Transport & 0,407 \\
\hline 2 & PT Gelang Trans & 0,134 \\
\hline 3 & PT Orient Future Lestari & 0,078 \\
\hline 4 & PT Pro - XT & 0,063 \\
\hline 5 & PT KMN Trans & $-0,537$ \\
\hline
\end{tabular}

\section{KESIMPULAN DAN SARAN}

\subsection{Kesimpulan}

1. Kriteria yang dibutuhkan dalam pembuatan laporan Skripsi mengenai pemilihan prioritas vendor dilihat dari pengurutan masing-masing kriteria adalah sebagai berikut:

a. Kualitas pelayanan vendor (Quality).

b. Harga (Price)

c. Pengiriman (Delivery)

d. Kemampuan vendor dalam memberikan pelayanan yang cepat dan tanggap. (Responsiveness)

e. Flexible (Flexibility)

2. Berdasarkan hasil perhitungan dengan Standardized Unitless Rating (SUR), maka diperoleh urutan prioritas vendor, yaitu sebagai berikut:

a. PT Pancaran Darat Trans dengan nilai SUR $=0,407$

b. PT Gelang Trans dengan nilai SUR $=0,134$

c. PT Orient Future Lestari dengan nilai SUR $=0,078$

d. PT Pro - XT dengan nilai SUR $=0,063$

e. PT KMN Trans dengan nilai SUR $=-0,537$

\subsection{Saran}

1. Untuk mempertahankan kinerja dan kualitas terbaik dari vendor, sebaiknya perusahaan melakukan evaluasi pengukuran kinerja vendor secara berkala, sehingga perusahaan tetap bekerjasama dengan vendor yang berkompeten.

2. Untuk dilakukannya mentoring terhadap vendor trucking, supaya vendor trucking mengetahui akan keinginan perusahaan kita, dan vendor trucking dapat menjalankan sesuai dengan keinginan perusahaan kita.

3. Lebih objektif dan selektif dalam menjalin hubungan kerja sama dengan vendor. 
4. Pihak perusahaan sebaiknya turut berperan serta dalam meningkatkan performansi vendor tujuannya untuk melahirkan hubungan kerja sama yang saling menguntungkan.

5. Pihak vendor terpilih diharapkan dapat meningkatkan kinerjanya demi terjalinnya hubungan kerjasama yang baik.

\section{DAFTAR PUSTAKA}

Ansori, Fuad. 2009. Analisis Kualitas Pelayanan Pengurusan Jasa Ekspor-Impor dan Angkutan dalam Upaya Meningkatkan Kepuasan Pelanggan dengan Menggunakan Metode QFD (Quality Function Deployment) di PT Askara Cargo Semesta

Asiyah, Nur Aulia. 2010. Analisis Pemilihan Prioritas Vendor dengan Standardized Unitless Rating di PT Transamudra Usaha Sejahtera (TRUST) Logistic Division)

Li et al. (1997), A new measure for supplier performance evaluation, IIE Transactions, Volume 29, Number 9

Made Dewi Lyana. 2010. Analisis Pemilihan Co-loader untuk Pengiriman Konsolidasi Barang Import LCL dari Negara-Negara Asia di PT Schenker Petrolog Utama dengan Menggunakan Metode Analytical Hierarchy Process (AHP)

Nasution, M Nur. 2004. Manajemen Transportasi. Jakarta: Ghalia Indonesia Saaty, Thomas L. 1993. Pengambilan Keputusan Bagi Para Pemimpin. Jakarta :PT Mustika Binaman Pressindo

Nur'aeni, Novi. 2009. Penilaian Kualitas Mitra Kerja Perusahaan Angkutan Darat di PT Askara Cargo Semesta dengan Fuzzy Synthetic Evaluation

Siswanto. 2007.Operation Research. Jakarta : ErlanggaTaha, Hamdy A.2007. Riset Operasi Jilid I. Tangerang : Binarupa Aksara Publisher

Supriatin, Cucu. 2010. Analisis Investasi Pengembangan Trucking Dengan Investasi Di Bank Central Asia (Studi Kasus Di PT Askara Cargo Semesta) 